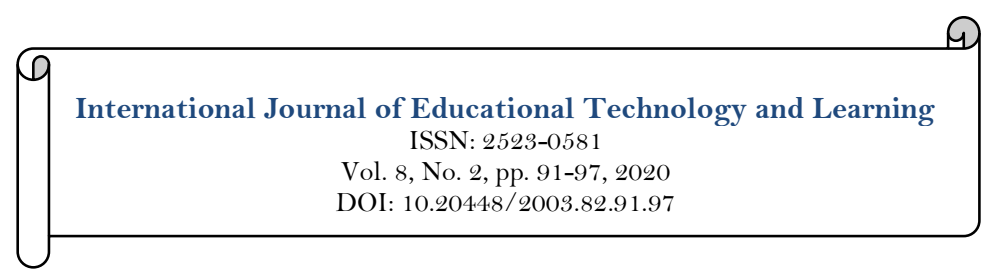

\title{
Teaching Biology in Primary Education
}

\section{Eirini Tzovla ${ }^{1 *}$ Katerina Kedraka ${ }^{2}$}

${ }^{1,2}$ Laboratory of Teaching and Professional Development of Bioscientists, Department of Molecular Biology and Genetics, Democritus University of Thrace, Greece.

Email:etzovla@mbg.duth.gr

\begin{tabular}{l|l}
\multicolumn{3}{|c}{ Abstract } & \\
This paper highlights the importance of teaching biological concepts in & Keywords: \\
Primary Education and the need for enhancement in students of scientific & Biological concepts \\
literacy in general and biological literacy in particular. The students should & Biological literacy \\
be aware of the reality they experience in order to make decisions as active & Curriculum \\
citizens and the teachers should use the best available methods and didactic & Inquiry-based learning \\
approaches to enhance students' scientific literacy and prepare them for their & Utilization of digital educational \\
real life. In this regard, it is important to build curricula that utilize & Content. \\
multiple learning resources and adopt student-centred methods and practices & \\
such as inquiry-based learning, collaborative learning and the use of digital & Licensed: \\
educational content. These approaches boost the 21 st-century skills through & This work is licensed under a \\
the active participation of students and improve the learning outcomes. & Creative Commons Attribution 4.0 \\
Hence, teachers play a significant role, because they should know those & License. \\
methods and practices to utilize in transmitting the scientific knowledge to & Publisher: \\
the students and teach effectively the biological concepts to them. & Scientific Publishing Institute \\
& Received: 15 July 2020 \\
& Revised: 19 August 2020 \\
& Accepted: 1 September 2020 \\
& Published: 11 September 2020
\end{tabular}

Funding: This study received no specific financial support.

Competing Interests: The authors declare that they have no competing interests.

\section{Introduction}

The teaching of Sciences is generally of great interest and their importance in the three (3) levels of education is catalytic both for the knowledge of the natural world and the laws that regulate it (National Research Council, 2012; OECD., 2010) and for the understanding of personal and social problems (Yager \& Penick, 1986). However, the teaching of Sciences in primary education is of great importance as the curiosity of students of this age should be used by teachers to help the students to think critically, express their opinion for social problems, and enhance their scientific literacy (Pedretti, 2002).

Among the Sciences is Biology, for which there is a strong interest, which is mainly related to the increase of social problems, environmental issues, new diseases, vaccinations and hygiene, malnutrition, reckless use of natural resources and which has an impact on the life of people. The recent COVID-19 pandemic highlights the urgent need to enhance scientific literacy (Fauzi et al., 2020) in general and biological literacy in particular, as 1.3 billion students from all levels of education in 142 countries were affected by the lockdown (UNESCO 2020). This clearly shows that the student should be aware of the reality they experience in order to make decisions as an active citizen (Bryce et al., 2011). Hence, this raises the question of whether the teachers use 
the best available methods and didactic approaches to enhance students' scientific literacy and prepare them for their real life. The student's engagement with biological concepts should be an inquiry-based process to boost their skills of scientific thinking and discovery of knowledge in authentic learning contexts; to orient and activate them to act on their own; to train them to act responsibly in matters concerning their life, the life of their family, and life on the planet; and ultimately, to help them become better acquainted with science, which will help them in their daily life (Rennie, Goodrum, \& Hackling, 2001).

In addition, it is worth to mention that the acquisition of the concepts of Sciences is based on pre-existing knowledge, and is the basis on which new knowledge will be built (Ausubel, 1968). Students' pre-existing knowledge and perceptions play a very important role in the acquisition of knowledge. Researchers Driver, Newton, and Osborne (2000); Pfundt and Duit (2004) have dealt with this issue and have concluded that students begin their school education with already formed perceptions on some topics, perceptions they insist might be wrong (misconceptions). Often, there are misconceptions, which are well-grounded and highly resilient to change (Chi \& Roscoe, 2002). The aim of the teaching is the modification of the existing misconceptions, their didactic transformation and the construct of the new knowledge.

Regarding students' misconceptions about biological concepts, the teachers could use them to approach the students creatively so as to lead to cognitive conflict and ultimately to the supplement or replacement of existing knowledge. This can be achieved through the adoption of methods and practices of inquiry-based learning, experiential learning (learning by doing) and the use of Digital Technologies, which enhance collaborative creativity, communication and 21 st-century skills and focus on observation and experimentation. Biological concepts cannot be approached individually because of their complexity and the relationships of interaction with other systems, but holistically (Barrett, Zhang, Moffat, \& Kobbacy, 2013) connecting with other cognitive objects and allowing the student to make connections between, concepts and situations. In addition, the approach to cognitive objects independently makes knowledge fragmentary and ultimately indifferent to students.

In this regard, the teacher plays a significant role, because he should not only possess the scientific knowledge but also know those methods and practices to utilize in transmitting the scientific knowledge to the students (Driver et al., 2000). Neuhaus (2007) classify Biology teachers into three types: a) the pedagogicallyinnovative teacher, who emphasizes in the importance of social interaction in the classroom, b) the innovative subject-oriented teacher, who incorporates students' experiences in teaching and experiments and c) the cognitive object-conventional teacher, who adopts the "traditional" way of teaching. All of them could offer themselves to the teaching of Biology.

In this paper, we presented the need to build curricula related to the teaching of biological concepts in Primary School, which use multiple learning resources with an emphasis on the use of digital educational content and student-centred teaching approaches.

\section{Literacy in Sciences}

The teaching of biological concepts in Primary Education aims to satisfy some objectives. This starts from the holistic approach of biological phenomena and involves the enhancement of scientific literacy, which the OECD (2007) reports as one's ability to use scientific knowledge, ask questions and export conclusions from data, understand the physical world and be able to make decisions about it and change caused by human activity. Bybee (2008) advocates that the term scientific literacy refers to the knowledge about Sciences but also the use of this knowledge, so that the student understands scientific issues, explains scientific phenomena and can export documented scientific conclusions; Bybee (2008) also, reports that existing curricula focus mainly on the content of the Sciences. In addition, Roth and Lee (2004) indicate that scientific literacy can be a tool in decision-making and encourages the organization of those learning environments that cultivate in students the skills of active participation in the community and then in society. Other researchers (Driver et al., 2000) have referred to scientific literacy as the understanding and interpretation of the world, the ability of individuals to solve problems, the understanding of scientific articles, the ability to make decisions about science and technology. Moreover, the PISA (OECD, 2007) program states that scientific literacy refers to the understanding of Sciences as a form of human knowledge and action. Scientific literacy contributes to the utilization of the acquired knowledge, skills and attitudes by students to interpret the environment in which they live and work, to adapt to the new conditions, to act as a group and to react as a community.

Therefore, there is an urgent need to build Curricula, which will empower students to implement interventions and actions related to the above and which according to Ibe (2009) will acquaint them with the scientific method of approaching knowledge and train them to enhance "metacognitive skills".

\section{Biology and Curriculum}

The curriculum structure is always related to decisions about the role of education and the characteristics of the literate and educated person that a society demands of its citizens. It essentially includes trends, goals, content, activities, practices and evaluation in the educational process. Petchey et al. (2015) report that there are at least three main models of curricula, which affect the teaching of Sciences in schools. These consist of 
scientific data and concepts (content), scientific nature and processes (behaviour or process) and their application to society (context).

Respectively, Hackling and Prain (2005) have recorded six (6) characteristics, which can contribute to the effective teaching of Sciences and which consist of the following: a) connection of the curriculum with the life and interests of the students b) connection of the classroom with the community c) enhancement of scientific literacy d) conceptual understanding of the Sciences e) evaluation, which facilitates learning and promotes scientific literacy and f) use of ICT to provide opportunities for interpretation and construction of multimodal representations. Fitzgerald (2012) Figure 1 formulates a conceptual model for the effective teaching of Sciences in Primary Education as follows:

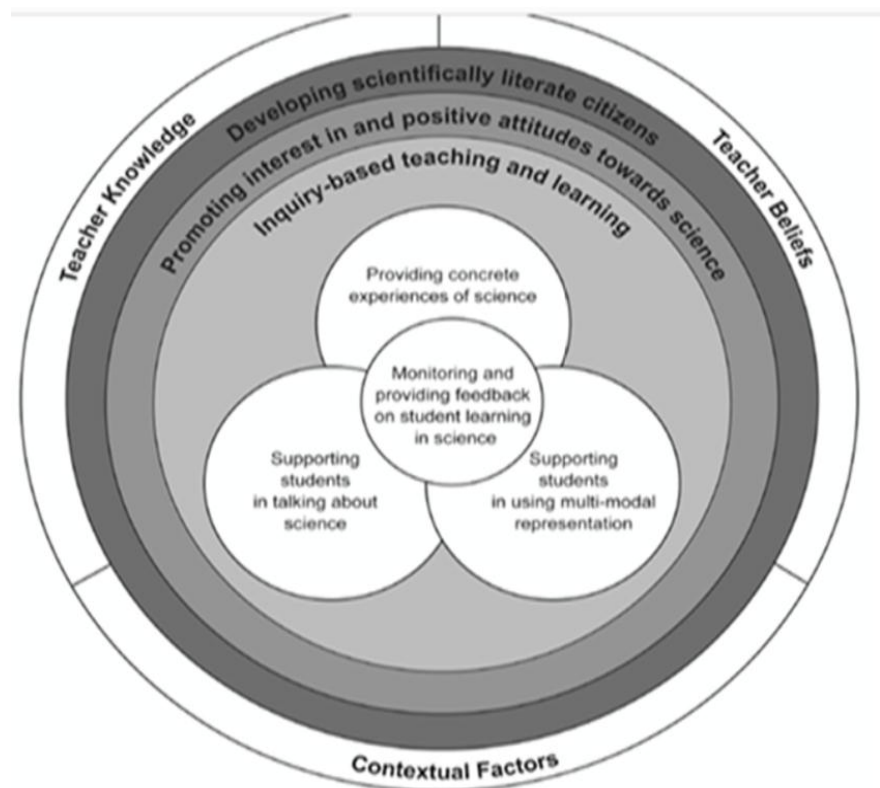

Figure-1. Conceptual model of components contributing to effective primary science teaching. Source: Fitzgerald (2012).

Focusing on the teaching of Biology, Schneider, Pakzad, and Schlüter (2013) state that it should help students to:

- Approach biological phenomena empirically.

- Approach concepts through inquiry-based learning by making and testing assumptions.

- Adopt the scientific language.

- Know the history of Sciences.

- Develop a rational worldview.

- Equip themselves with a body of knowledge and strategies, which orient them towards technology and Sciences, focused occupations.

Given that curricula are linked to textbooks, it is common practice for the knowledge to be approached mainly through them, which are usually the only recourse for students and teachers (Alexander, Kulikowich, \& Jetton, 1994) and dictate what and how to teach a subject (Kesidou \& Roseman, 2002). The textbooks that teach biological concepts are not an exception. For this reason, the elementary school teachers, who teach biological concepts, should encourage the use of multiple resources and material they can adapt, modify and configure according to the needs of their students. Carlan, Sepel, and Loreto (2014) report that utilizing multiple learning resources that actively engage students has improved their ability to understand both specific and abstract biological concepts compared to students who used only the textbook. In addition, elementary school teachers should use and integrate into their teaching the knowledge and experiences of students to make connections in other Sciences, in order to highlight interdisciplinary. These create new perspectives and forms of research (Aktas, 2015) utilize authentic learning environments, support active student participation, collaboration and experiential learning, and integrate feedback activities for both teacher and student learning partners.

The review of the Sciences curricula in Primary Education in developed countries such as Finland, Germany, England, Australia and others concluded that they follow a common philosophy of acquiring knowledge and skills, which push the student to research and social participation. These curricula approach the basic concepts of Sciences not by focusing on detailed scientific knowledge and memorization but by emphasizing the enhancement of flexibility and critical thinking, social skills and action in the immediate environment. 


\section{Didactic Approaches to the Teaching of Biological Concepts in Primary School}

We live in a volatile, uncertain, complex, and ambiguous environment. Hence, one of the main goals of the school is to enhance skills in its students, so that they can build their knowledge in the future. Therefore, there is a need to change and improve the educational process and understand that the mere acquisition of knowledge is not enough for students, but that they need to cultivate the so-called 21 st-century skills, such as collaboration, communication, creativity, and critical thinking. The enhancement of these skills is achieved by utilizing appropriate educational approaches, which can support learning in various cognitive subjects. Regarding the biology course, Jeronen, Palmberg, and Yli-Panula (2017) in a meta-research they conducted on the most appropriate teaching methods for teaching Biology came up with 22 student-centred teaching approaches, which are proposed to take place in authentic learning environments. Of these, greater emphasis is placed on teamwork and collaboration, active and interactive participation and support in teaching practice.

The teaching of biological concepts in the Primary School is demanding, as many of the concepts are abstract and as some of them that were previously taught in the High School are now being taught in the Primary School. If one takes into consideration that, according to Piaget, elementary school students go through the stage of specific logical thinking (Huitt \& Hummel, 2003) one realizes that the effective teaching of biological concepts is a challenge for the teacher. Other researchers such as Driver and Oldham (1986) and Lourenço and Machado (1996) argue that Piaget underestimates children's abilities and students can approach and understand abstract concepts by choosing appropriate paths. However, Cajaiba-Santana (2014); Chavan (2016) point out that teachers face difficulties in teaching biological concepts and that the difficulties include lack of teaching aid, lack of time and lack of sufficient material. Numerous research (Lewis, Peat, \& Franklin, 2005; Spiegel et al., 2008) show that the approach of biological concepts through innovative teaching practices and "non-conventional" classrooms, which utilize the active involvement of students, could contribute to the effective teaching of the concepts. Such approaches, which can effectively support the teaching of biological concepts in Primary Education, are the inquiry-based learning, the collaborative learning and the project method and the utilization of digital educational content and the Open Educational Recourses (OER). The adoption of one approach does not exempt the others and their combination can effectively assist the teaching of biological concepts.

Inquiry-based learning refers to two types of learning: learning through discovery and learning through inquiry, which are often used as synonyms. Harsh, Maltese, and Tai (2011) report that a key difference between the two approaches is that while learning through discovery is teacher-centred, learning through inquiry is student-centred. Teachers through inquiry learning should develop students' cognitive abilities; bring them in contact with the scientific method and those teaching strategies that will enhance their skills in data interpretation and scientific research (National Research Council, 1996). The essence of inquiry learning, for Avery and Meyer (2012) and Cunningham (1995) is to educate students to ask questions, to decide which methodology to follow, to observe, to collect data, to refer to variables, to anticipate the consequences of an intervention, to compare, act, measure, test hypotheses, communicate results to peers, act as scientists, think critically and solve hands-on problems, skills that can be used in the enhancement of biological literacy. Furthermore, inquiry learning through the implementation of laboratory exercises allows students to experiment, observe record, generalize and export conclusions, and then scientifically approach the biological concept. Eisenkraft (2003) proposes the model of the "5E Learning Cycle" as a model for the application of inquiry learning in the classroom. The model consists of the following: Involvement, Exploration, Explanation, Processing, and Assessment-Evaluation.

Collaborative learning is theoretically based on the theory of social constructivism. This theory argues that knowledge is a social construct and learning a social process (Vygotsky, 1986). Johnson and Johnson (2002) report that students working in collaborative learning conditions show improved learning results. Collaborative learning promotes positive interdependence and, as mentioned above, Jeronen et al. (2017) postresearch classifies it as one of the most appropriate methods of approaching biological concepts, while Lorsbach and Tobin (1995) claim that peer feedback contributes positively to the achievement of the common goal and Effandi and Zanaton (2007) refer to collaborative learning as one of the most effective ways of learning due to collaboration between its members. This didactic approach can be combined with the project method, which utilizes the experiences, concerns and interests of students, which are then organized within a communicative context of interactive relationships. Helm and Katz (2011) point out that this method focuses on a holistic approach to knowledge, boosts multiple intelligences and is offered for experiential, multimodal and collaborative activities, which are suitable for teaching biological concepts. The project method encourages students to learn through many different contexts, to think critically, to be actively involved, to argue, to share the responsibility for their learning, to enhance their creativity and imagination and to practice the scientific way of thinking (Anderson, 2002; Yoon \& Onchwari, 2006).

Utilization of technology and digital educational content can help to bring about educational change. This is because new technologies are available and have led to the development of digital educational resources that allow students to examine phenomena that cannot be studied in the classroom and to draw conclusions about them, to implement projects for which the school cannot provide the necessary equipment, collaborate with other students and/or research teams anywhere in the world, become members of educational and student 
networks and share knowledge, practices and experiences. The utilization of technology and digital educational content in combination with the appropriate didactic approach brings students into contact with biological phenomena that cannot be observed through the eye and allows them to experiment, which in the real world would probably create fear and insecurity for them to attempt, as technology does not involve the risk of injury or the consequences of a wrong move during the implementation of an experiment. The utilization of the digital educational content proves to be particularly useful in the case of schools that do not have either a laboratory or the appropriate material and technical infrastructure that allows the transaction of biology laboratory experiments. In this case, digital educational content can help with a great number of resources which it offers. This kind of resource is the audio-visual material that allows the observation of phenomena, and functions, which require time to complete, and the access to images, diagrams and tables that capture the evolution of phenomena and functions (Kim, Vaughn, Wanzek, \& Wei, 2004). Kelley et al. (2008) observe that image analysis offers an understanding of the structure and function of biological concepts through process visualization. Similarly, Wang, Yu, and Huang (2013) in a study in Taiwan found that students who watched science-related programs on television performed better in Biology and Veselinovska (2015) emphasizes the importance of using animation in teaching Biology. She used animation to teach cell structure and cell division and concluded that the visualization of biological concepts contributed to the understanding of the phenomenon, as the complex and abstract process of cell structure and division was concretized and the process was remembered by the students.

Also, important is the contribution of concept maps to the teaching of Biology, which can be used as organizers for the teaching of biological concepts and which facilitate students to integrate the individual components of biological knowledge into a broader conceptual framework (Bramwell-Lalor \& Rainford, 2014). Schmid and Telaro (1990) and Kinchin, Hay, and Adams (2000) point out that concept maps, by visualizing students' basic ideas, highlight essential and creative learning and activate pre-existing knowledge. Biological concepts often depict the relationships between different functions, and visualizations help students make the necessary connections and create such cognitive models that allow them to grasp abstract concepts.

In addition, the contribution of simulations to the teaching of biological concepts is of great importance, as they create authentic learning environments, boost discovery (Peat \& Fernandez, 2000) allow the student to change parameters that determine the outcome of a phenomenon or function and familiarize students with the scientific way of thinking. Moreover, students who learn through simulations can better improvise in a real environment, can handle unexpected situations, and that the knowledge they acquire is not structured around a set of rules or procedures, but develops with inherent personal experience. Bidarra and Martins (2010) in their research examined the use of simulation material, which was tested in primary and secondary school students and was related to the idea of connecting the real environment of nature with the virtual environment of a multimedia simulator and an electronic game. They came up with encouraging results for the contribution of simulations to the teaching of biological concepts. Simulations allow the dynamic representation of biological phenomena, accurately and vividly depict microcosms, enable students to ask questions and make accessible complex and multidimensional processes (Schönborn \& Anderson, 2006).

Furthermore, virtual environments are interactive, safe, provocative, allow the manipulation of virtual situations in proportion to real situations, the virtual contact with the microcosms of biological concepts, the study of phenomena with which students cannot come into contact in the real world (ultrasound, infrared light, etc.), the transformation of abstract concepts into perceptual representations and offer experiential learning experiences. Therefore, they can support the teaching of biological concepts in Primary School. An example is the research of Ferdig, Cavanaugh, DiPietro, Black, and Dawson (2009) who utilized virtual environments to evaluate the effectiveness of the use of stereoscopic images in the teaching of biological concepts. The results indicate that students who learned the phenomenon using 3D technology had statistically significant differences and improved learning outcomes compared to their classmates who learned the phenomenon without the use of 3D images. Respectively, Slepchenko, Schaff, Macara, and Loew (2003) report the case of the Boston Museum of Technology, which created Cell Biology, which is a virtual interactive environment for biological concepts, while Karr and Brady (2000) created a similar virtual environment at the University of Chicago.

Shim et al. (2003) used virtual learning environments and simulations to teach the eye to an elementary school in Korea and found that students' interest and understanding of biological concepts increased, and Mikropoulos, Katsikis, Nikolou, and Tsakalis (2003) used virtual reality environments in teaching the biological concepts of plant cell and photosynthesis in a course for the elementary teachers. The results indicate that teachers believe that these environments can be supportive of the educational process and that they have many advantages.

\section{Conclusions}

In conclusion, it is of great importance the teaching of biological concepts in Primary Education and the preparation of curricula, which enhance scientific literacy and 21 st-century skills through the active participation of students and the use of multiple resources and teaching resources that the internet offers (Peat \& Fernandez, 2000). Muppudathi and Pazhanivelu (2012) report that digital educational content is an effective 
tool in teaching Biology in schools and concepts are expressed in a variety of ways and multi-sensory promote multiple connections and the integration of new knowledge into old. The above approaches, however, presuppose that teachers not only have knowledge of the subject, pedagogy and technology but are also able to combine them to teach their students effectively.

\section{References}

Aktas, C. B. (2015). Reflections on interdisciplinary sustainability research with undergraduate students. International Journal of Sustainability in Higher Education, 16(3), 354-366. Available at: 10.1108/ijshe-11-2013-0153.

Alexander, P. A., Kulikowich, J. M., \& Jetton, T. L. (1994). The role of subject-matter knowledge and interest in the processing of linear and nonlinear texts. Review of Educational Research, 64(2), 201-252.

Anderson, R. D. (2002). Reforming science teaching: What research says about inquiry. Journal of Science Teacher Education, 13(1), 1-12. Available at: https://doi.org/10.1023/a:1015171124982.

Ausubel, D. (1968). Educational psychology: A cognitive view. New York: Holt, Rinehart \& Winston.

Avery, L. M., \& Meyer, D. Z. (2012). Teaching science as science is practiced: Opportunities and limits for enhancing preservice elementary teachers' self-efficacy for science and science teaching. School Science and Mathematics, 112(7), 395-409. Available at: https://doi.org/10.1111/j.1949-8594.2012.00159.x.

Barrett, P., Zhang, Y., Moffat, J., \& Kobbacy, K. (2013). A holistic, multi-level analysis identifying the impact of classroom design on pupils' learning. Building and Environment, 59, 678-689. Available at: https://doi.org/10.1016/j.buildenv.2012.09.016.

Bidarra, J., \& Martins, O. (2010). Exploratory learning with Geodromo: Design of emotional and cognitive factors within an educational cross-media experience. Journal of Research on Technology in Education, 43(2), 171-183. Available at: https://doi.org/10.1080/15391523.2010.10782568.

Bramwell-Lalor, S., \& Rainford, M. (2014). The effects of using concept mapping for improving advanced level biology students' lower-and higher-order cognitive skills. International Journal of Science Education, 36(5), 839-864. Available at: https://doi.org/10.1080/09500693.2013.829255.

Bryce, R., Oliver, M. K., Davies, L., Gray, H., Urquhart, J., \& Lambin, X. (2011). Turning back the tide of American mink invasion at an unprecedented scale through community participation and adaptive management. Biological Conservation, 144(1), 575-583. Available at: https://doi.org/10.1016/j.biocon.2010.10.013.

Bybee, R. W. (2008). Scientific literacy, environmental issues, and PISA 2006: The 2008 Paul F-Brandwein lecture. Journal of Science Education and Technology, 17(6), 566-585. Available at: https://doi.org/10.1007/s 10956-008-9124-4.

Cajaiba-Santana, G. (2014). Social innovation: Moving the field forward. A conceptual framework. Technological Forecasting and Social Change, 82, 42-51. Available at: https://doi.org/10.1016/j.techfore.2013.05.008.

Carlan, F. D. A., Sepel, L. M. N., \& Loreto, E. L. S. (2014). Teaching cell biology in primary schools. Education Research International, 2014, 1-5. Available at: https://doi.org/10.1155/2014/272475.

Chavan, R. (2016). Difficulties in teaching biology concepts by science teachers at upper primary level. Online Submission, $3(8), 10-18$.

Chi, M. T., \& Roscoe, R. D. (2002). The processes and challenges of conceptual change. In Reconsidering conceptual change: Issues in theory and practice (pp. 3-27). Dordrecht: Springer.

Cunningham, S. A. (1995). Problems with null models in the study of phylogenetic radiation. Evolution, 49(6), 1292-1294.

Driver, R., Newton, P., \& Osborne, J. (2000). Establishing the norms of scientific argumentation in classrooms. Science Education, 84, 287-312. Available at: https://doi.org/10.1002/(SICI)1098-237X(200005)84:3<287::AIDSCE1>3.0.CO;2-A.

Driver, R., \& Oldham, V. (1986). A constructivist approach to curriculum development. Science Studies in Science Education, 13, 105-122. Available at: https://doi.org/10.1080/03057268608559933.

Effandi, Z., \& Zanaton, I. (2007). Promoting cooperative learning in science and mathematics education: A Malaysian perspective. Eurasia Journal of Mathematics, Science and Technology Education, 3(1), 35-39.

Eisenkraft, A. (2003). Expanding the 5E model. Science Teacher-Washington, 7O(6), 56-59. Available at: 10.12691/education6-1-12.

Fauzi, A., Husamah, H., Miharja, F. J., Fatmawati, D., Permana, T. I., \& Hudha, A. M. (2020). Exploring COVID-19 literacy level among biology teacher candidates. Eurasia Journal of Mathematics, Science and Technology Education, 16(7), em 1864. Available at: https://doi.org/10.29333/ejmste/8270.

Ferdig, R. E., Cavanaugh, C., DiPietro, M., Black, E. W., \& Dawson, K. (2009). Virtual schooling standards and best practices for teacher education. Journal of Technology and Teacher Education, 17(4), 479-503.

Fitzgerald, A. (2012). Science in primary schools: Examining the practices of effective teachers: Springer Science \& Business Media. Available at: 10.1007/978-94-6091-858-2.

Hackling, M., \& Prain, V. (2005). Primary connections. Australia: Australian Academy of Science.

Harsh, J. A., Maltese, A. V., \& Tai, R. H. (2011). Undergraduate research experiences from a longitudinal perspective. Journal of College Science Teaching, 41(1), 84-90.

Helm, J., \& Katz, L. (2011). Young investigators: The project approach in the early years. New York: Teachers College Press.

Huitt, W., \& Hummel, J. (2003). Piaget's theory of cognitive development. Educational Psychology Interactive, 3(2), 1-5.

Ibe, H. N. (2009). Metacognitive strategies on classroom participation and student achievement in senior secondary school science classrooms. Science Education International, 20(1/2), 25-31.

Jeronen, E., Palmberg, I., \& Yli-Panula, E. (2017). Teaching methods in biology education and sustainability education including outdoor education for promoting sustainability-A literature review. Education Sciences, 7(1), 1. Available at: 10.3390/educsci7010001.

Johnson, D. W., \& Johnson, R. T. (2002). Learning together and alone: Overview and meta-analysis. Asia Pacific Journal of Education, 22(1), 95-105. Available at: https://doi.org/10.1080/0218879020220110.

Karr, T. L., \& Brady, R. (2000). Virtual biology in the CAVE. Trends in Genetics: TIG, 16(5), 231-232. 
Kelley, B. D., Tobler, S. A., Brown, P., Coffman, J. L., Godavarti, R., Iskra, T., \& Vunnum, S. (2008). Weak partitioning chromatography for anion exchange purification of monoclonal antibodies. Biotechnology and Bioengineering, $101(3), 553-566$.

Kesidou, S., \& Roseman, J. E. (2002). How well do middle school science programs measure up? Findings from Project 2061 's curriculum review. Journal of Research in Science Teaching, 39(6), 522-549.

Kim, A.-H., Vaughn, S., Wanzek, J., \& Wei, S. (2004). Graphic organizers and their effects on the reading comprehension of students with LD: A synthesis of research. Journal of Learning Disabilities, 37(2), 105-118. Available at: https://doi.org/10.1177/00222194040370020201.

Kinchin, I. M., Hay, D. B., \& Adams, A. (2000). How a qualitative approach to concept map analysis can be used to aid learning by illustrating patterns of conceptual development. Educational Research, 42(1), 43-57. Available at: https://doi.org/10.1080/001318800363908.

Lewis, A., Peat, M., \& Franklin, S. (2005). Understanding protein synthesis: An interactive card game discussion. Journal of Biological Education, 39(3), 125-130. Available at: https://doi.org/10.1080/002 19266.2005.9655979.

Lorsbach, A., \& Tobin, K. (1995). Toward a critical approach to the study of learning environments in science classrooms. Research in Science Education, 25(1), 19-32. Available at: https://doi.org/10.1007/bfo2356457.

Lourenço, O., \& Machado, A. (1996). In defense of Piaget's theory: A reply to 10 common criticisms. Psychological Revierw, 103(1), 143-164. Available at: https://doi.org/10.1037/0033-295x.103.1.143.

Mikropoulos, T. A., Katsikis, A., Nikolou, E., \& Tsakalis, P. (2003). Virtual environments in biology teaching. Journal of Biological Education, 37(4), 176-181.

Muppudathi, G., \& Pazhanivelu, G. (2012). Effect of econtent on teaching biology at secondary level. Journal of Contemporary Educational Research and Innovations, 2(2), 3 1-33.

National Research Council. (1996). National science education standards. Washington, DC: The National Academies Press.

National Research Council. (2012). Education for life and work: Developing transferable knowledge and skills in the 21st century. Washington, DC: The National Academies Press.

Neuhaus, B. (2007). Quality of teaching as a research field for empirical biological didactic studies. In theories in biological didactic research (pp. 243-254). Berlin, Heidelberg: Springer.

OECD. (2007). PISA 2006: Science competencies for tomorrow's world: Analysis (Vol. 1). Paris: PISA, OECD Publishing.

OECD., O. E. C. D. (2010). Factbook 2013: Economic, environmental and social statistics. Paris: Organization for Economic Cooperation and Development.

Peat, M., \& Fernandez, A. (2000). The role of information technology in biology education: an Australian perspective. Journal of Biological Education, 34(2), 69-73. Available at: 10.1080/00219266.2000.9655688.

Pedretti, E. (2002). T. Kuhn meets T. Rex: Critical conversations and new directions in science centers and science museums. Studies in Science Education, 36, 1-42. Available at: https://doi.org/10.1080/03057260208560176.

Petchey, O. L., Pontarp, M., Massie, T. M., Kéfi, S., Ozgul, A., Weilenmann, M., \& Childs, D. Z. (2015). The ecological forecast horizon, and examples of its uses and determinants. Ecology Letters, 18(7), 597-611. Available at: https://doi.org/10.1111/ele.12443.

Pfundt, H., \& Duit, R. (2004). Bibliography: Students' and teachers' conceptions and science education. Kiel: IPN.

Rennie, L. J., Goodrum, D., \& Hackling, M. (2001). Science teaching and learning in Australian schools: Results of a national study. Research in Science Education, 31(4), 455-498. Available at: 10.1023/A:1013171905815.

Roth, W. M., \& Lee, S. (2004). Science education as/for participation in the community. Science Education, 88(2), $263-291$.

Schmid, R. F., \& Telaro, G. (1990). Concept mapping as an instructional strategy for high school biology. The Journal of Educational Research, 84(2), 78-85. Available at: https://doi.org/10.1080/00220671.1990.10885996.

Schneider, C., Pakzad, U., \& Schlüter, K. (2013). The influence of personal school experience in biology classes on the beliefs of students in university teacher education. Journal of Education and Training Studies, 1(2), 197-210. Available at: https://doi.org/10.11114/jets.v1i2.146.

Schönborn, K. J., \& Anderson, T. R. (2006). The importance of visual literacy in the education of biochemists. Biochemistry and Molecular Biology Education, 34(2), 94-102. Available at: 10.1002/bmb.2006.49403402094.

Shim, S. M., Lee, K. R., Kim, S. H., Im, K. H., Kim, J. W., Lee, U. Y., \& Lee, T. S. (2003). The optimal culture conditions affecting the mycelial growth and fruiting body formation of Paecilomyces fumosoroseus. Mycobiology, $31(4), 214-$ 220. Available at: 10.4489/MYCO.2005.33.1.065.

Slepchenko, B. M., Schaff, J. C., Macara, I., \& Loew, L. M. (2003). Quantitative cell biology with the Virtual Cell. Trends in Cell Biology, 13(11), 570-576. Available at: 10.1016/j.tcb.2003.09.002.

Spiegel, C. N., Alves, G. G., Cardona, T. D. S., Melim, L. M., Luz, M. R., Araújo-Jorge, T. C., \& Henriques-Pons, A. (2008). Discovering the cell: An educational game about cell and molecular biology. Journal of Biological Education, 43(1), 27-36.

UNESCO (2020). COVID-19 and higher education: Today and tomorrow. Retrieved from: http://www.iesalc.unesco.org/en/wp-content/uploads/2020/04/COVID-19-EN- 090420-2.pdf.

Veselinovska, S. S. (2015). Impact of the usage of animation in teaching cell biology on student achievement. Paper presented at the Book of Selected Papers, Conference: Researching Paradigms of Childhood and Education, At Opatija, CROATIA 13-15.4.2015.

Vygotsky, L. S. (1986). Thought and language. Cambridge, MA: MIT Press.

Wang, W., Yu, G., \& Huang, A. (2013). Cognitive radio enhanced interference coordination for femtocell networks. IEEE Communications Magazine, 51(6), 37-43. Available at: 10.1 109/MCOM.2013.6525593.

Yager, R. E., \& Penick, J. E. (1986). Perceptions of four age groups toward science classes, teachers, and the value of science. Science Education, 70(4), 355-363. Available at: https://doi.org/10.1002/sce.3730700402.

Yoon, J., \& Onchwari, J. A. (2006). Teaching young children science: Three key points. Early Childhood Education Journal, $33(6), 419-423$. 